\title{
International Market Segmentation: Exploring Cell Phone Market of Young Adults
}

\author{
Mahmood A. Awan
}

\begin{abstract}
Purpose: The purpose of this paper is twofold: to investigate the possible inter-market segments in cell phone markets of South Korea and China among young adults and secondly, to summarize and overview previous empirical international segmentation studies in this area to bring the issues together.

Design/Methodology/Approach: The data for the study were collected from college-age cell phone users in South Korea and China. A total of 331 questionnaires were deemed as usable for data analysis. Ordered logistic regression analyses were used to test the conceptual model.

Findings: The results of the study suggest the inter-market segments do exist in S. Korea and China. These inter-market segments include gender, brand, usage, and features. Further, the evaluation of previous such studies on Finland, USA, Canada, New Zealand and UAE show that inter-market segments are valid for cell phone industry.

Practical Implications: The inter-market segments do extend over the borders of S. Korea and China. Considering the size of China market, these inter-market segments can be very for telecommunication companies as well as cell phone manufacturers to offer unique products, services, and miscellaneous marketing program extending the international borders.

Originality/Value: The paper is unique in that it is one of the first to not only compare the $S$. Korean and Chinese cell phone market of young adults, but also to consolidate up to date research on this subject for various countries.
\end{abstract}

Index Terms-Cell phone college users, China and South Korea, international market segments, cell-phone features, log-it regression analysis, Inter-market segments.

\section{INTRODUCTION}

Consumers around the world vary tremendously in demographic, cultural, social, and psychological characteristics. The young adult segment is very attractive to marketers both in terms of its size and its multi-billion dollar purchasing power [1]. In the marketing literature youth culture has been held up as the prototypical example of a global segment.

Globalization has opened doors for youngsters from New York, Tokyo, Hong Kong, to those from Paris, London, and Seoul to share memorable experiences (through television, international education, and frequent travel) which are reflected in their common consumption behavior. As noted by [2], "a short hand way to market the advent and impact of globalization is to point to the evidence of global youth consuming practices". For marketers and consumers alike,

Manuscript received August 1, 2013; revised October 4, 2013.

Mahmood A. Awan is with SolBridge International School of Business, Daejeon, CO 300-814 South Korea (e-mail: mawan@ Solbridge.ac.kr). such signs of a global youth culture are all too readily treated as obvious evidence of homogenized group of consumers.

One possible homogenized group of consumers is young adults' preference of Cell (mobile) phones. Cell phones were originally used for business interaction. However, after their popularity, they are being used more often for social and personal reasons such as talking to friends, SMS, E-mail, Internet browsing, and games, especially by young adults.

Some research on inter-market segments relative to cell phone has been recently published [3]-[7]. However, a systematic overview on this subject is not available. The current paper presents an overview of the previous empirical studies on this subject. Previous studies have raised issues in establishing inter-market segments in mobile phone market for young adults. These conceptual and methodological issues deserve more attention if such inter-market segments, is to fulfill its potential. Further, this research compares $S$. Korean and Chinese college students in respect to their preference for different features. Finally, a comparison is made with the previous studies to make recommendations for the cell phone industry and marketers.

The remainder of this paper is organized as follows. Following the introduction, the second section provides a relative literature review on both inter-market market segments in the international context for cell phones and possible segments among the adolescents and young adults. The third section presents the research methods use, and analyses. The fourth section discusses the results and the findings of this study. Finally, the study concludes with a discussion of the limitation of the study, and the future research in this field is presented as well.

\section{LITERATURE REVIEW}

International segmentation aids a firm in structuring the heterogeneity that exists among consumers and nations and helps to identify segments that can be targeted in an effective way. International segmentation offers a solution to the standardization versus adaptation debate in that it creates the conceptual framework for offering product and/or marketing programs that are standardized across countries by targeting the same consumer segment(s) in different countries.

When using similar marketing strategy in multiples countries, economies of scale will lead to the reduction in the average costs of production, advertising, and distribution. Hence, international segmentation combines the benefits of standardization (e.g. lower costs, better quality) with benefits of adaptation (e.g. close to needs of consumers).

Research in inter-market segments relative to cell phones has been recently published. Haverila (2013) [3] has investigated the existence of inter-market segments in the 
adolescents' and young adults' cell phone product-market in Finland, United Arab Emirates, Canada, China, and New Zealand. The results of the study suggest the inter-segments do exist in the countries of this study, but their existence varies to some degree by country. Similarly, [8] has studied the college-goers cell phone users of one of the fastest growing telecommunication market of India. The findings show that there is a significant difference in the usage pattern of mobile phones because of three variables which could be compared with study from other countries.

Haverila (2011) [4] has also investigated the cell phone use and broad cell phone feature preferences among high school and undergraduate students of Finland. It was reported that there were significant gender differences in the use of cell phone features. McLeod (2009) attempted to uncover whether baby boomers have embraced cell phone technology. The results indicated that although baby boomers' general uptake of mobile phone technology was high, they have a limited use and understanding of functions beyond voice calls and SMS.

Young consumers in every part of the world are more diverse and fast changing than any other demographic group. Every marketer in any part of the world has to learn quickly about the changes in young consumers in order to swiftly introduce modifications and to introduce a highly creative marketing mix. Thus understanding young consumers' social, cultural, psychological, and behavioral nature is important for marketers not only in targeting but also for influencing parents' decisions. The market segment of young consumer changes the rules of the market due to frequently changing preferences in choosing products and services.

The young adults segment is attractive in terms of its size and its multibillion dollar purchasing power [1]. In the marketing literature youth culture has been held up as the prototypical example of global segment. Global teens from New York, Tokyo, Hong Kong, to those from Paris, London, and Seoul share memorable experiences (through television, international education, social media, and frequent travel) which has reflected in their consumption behavior.

As reported by [9], in South Korea a mobile internet-enabled phone has become recognized as a necessity in daily life, not just as a communication device. It is easy to find South Koreans using mobile internet-enhanced phones to read e-books, watch movies, chat with friends, and play games or trade stocks anywhere and anytime. Further, South Koreans view the mobile phone as more expensive, more stylish, and more of a necessity than do Americans, as reported by [10]. In short, it appears that the mobile phone has made a positive impression on South Korean society.

Results of a survey on mobile phone and internet use conducted by [11] showed teenagers $(80.4 \%)$ and the 20 year olds $(85 \%)$ showed much higher use rate in comparison with people in their 30s $(55.3 \%), 40 \mathrm{~s}(33.5 \%)$, and 50s (14.9\%). The data clearly demonstrates that college students are the most active mobile communication users in Korea. Thus Young adults and the generation who have received benefits from ICT developing in the Korean context and who also have been relatively more active users of ICT's rather than older generation.

Im, Hong and Kang (2011) [12] reported that mobile technology has been more widely adopted for a longer time in South Korea than in the USA. South Korea is widely recognized for its world leadership in embracing mobile technology, including smart-phones. For example South Korea has the highest rate of mobile device adoption in the world [13]. In other words South Korea is renowned for embracing the mobile phone in is emerging as the world leader for mobile phone use.

A [14] study has also reported that young people around are the world biggest adopters of mobile technology. According to the report, $73 \%$ of Chinese youth age $15-24$ citied mobile internet usage. By comparison, less than half of American and British cell-phone youths used the Internet from their mobile devices.

Technology Acceptance Model (TAM) theory indicates that perceived ease of use and perceived usefulness predict the acceptance of technology [15]. McLeod (2009) [6] study has demonstrated that regarding the cell phone communication, age can indeed predict the usage of mobile technology. Based on the study [16] one can assume that the cell phone producers manufacture handsets for general market segment called "macro segments". However the characteristics of smaller "micro segments" existing among the adolescent and young adult cell phone users extending the borders, has yet to be established. Kamaluzaman (2006) [17] has shown that in the TAM framework, the user characteristics of mobile technology like age is treated as an eternal variable and user acceptance operators through central believes.

The cell phone set features can and have been used for segmentation purposes. Adding too many features can lead to small keys and it can cause cell phone launch success rates to deteriorate [18]. Thus [19] developed a feature set for the evaluation of cell phones. They divided it in two types of criteria, the product related and user related. For example they may include memory, games, ringtones, and brand, technical support etc.

Oksaman (2010) [20] has shown that the social interaction in reference to college cell phone usage appears to be dominant since they perceive mobile communication as more 'liberating" and providing "independence". The cell phone set features can and have been used for segmentation purposes. Adding too many features can lead to small keys and it can cause cell phone launch success rates to deteriorate [18]. Thus [19] developed a feature set for the evaluation of cell phones. They divided it in two types of criteria, the product related and user related. For example they may include memory, games, ringtones, and brand, technical support etc.

In spite of the growing importance of globalization forces which push their domestic based marketing strategies across borders, market segmentation studies in the international context is rather limited. A few market studies on segmentation of cell phones are available, but they are mostly country specific. For example [21] studied for the Italian market, [22] in the Austrian market, and the US market.

Dibb and Simkin (2010) [23] is the first robust multi-country study aimed to test the quality of segmentation using a longitudinal case study of the Eastern European market. However, even though for this research data was 
from multiple countries, it is difficult to establish whether true international segments exist.

Thus it is obvious that there is a strong need for more segmentation research in the cell phone market especially among the young adults since this age group is driving the market to new directions and usage. Haverili (2013) [3] has recently study on Finland, United Arab Emirates, Canada, China, and New Zealand, suggest the existence of inter-market market segments but their existence varies to some degree by the country. However, the current study extends it further to include South Korea as well.

Thus the current study focuses on the perceived service quality of online banking. The study covers customer of the China and Saudi Arabian Markets. Both contries have significant importance in their respective regions. With this study we can compare the cultures. Further, the outcome of the study can guide bankers of both countries to apply any commonalities among their customers perception of online quality.

\section{RESEARCH MethodS AND ANALYSES}

In order to investigate possible inter-market market segments in both China and South Korea, a survey was conducted in both countries (questionnaire can be found in online version). Date was collected from for undergraduate university students of both countries. The first section of the questionnaire sought demographic information from the respondents. Also, respondents were asked to rate the importance of a set of cell phone feature preferences cited by [19]. These features were assessed using Likert-type questions with responses ranging from "Very important" (7) to "Very unimportant", (1). The reliabilities were calculated for each dimension. A cluster sampling method was used similar to one used by [24] In addition the respondents were asked to report the frequency of usage of specific cell phone functions. These included the use of phone, SMS, MMS, games, camera+ video, music, E-mail, internet, calendar and calculator. These were important for the interpretation of the results of the segmentation study.

\section{A. Data Collection and Statistical Analysis}

Data were collected using a convenience sample of 400 Chinese and Korean university students however, a total of 331 questionnaires were deemed as usable for data analysis. The questionnaire consisted of four sections. In the first section, respondents are asked to provide their demographic information, including gender, education, age, and nationality etc.

In the following section, respondents were asked to evaluate the product related feature preferences of cell phones. The features included basic requirements, physical characteristics, and technical features. In the next section of the questionnaire, respondents were asked to give their preference of the product features from the user point of view. Thus it included functionality, brand choice, and technical support etc. The frequency of use of the students' cell phone features were evaluated in the last section of the questionnaire.

As it appears, the first significant difference between two samples is nationalities. The proportion of Korean to Chinese in total respondents is approximately half-half $(51 \%-49 \%)$, while about $60 \%$ of all the respondents are male.

Statistical analysis of this study was conducted using cluster analysis via SPSS (v.20.0). A 2-step cluster analysis was done as performed by [3] for similar type of studies. The 2-step approach was chosen since it enables the optimal combination of the advantages and disadvantages of the hierarchical and non-hierarchical methods.

\section{B. Cluster Analysis Results}

After the two step process starting with hierarchical cluster analysis, five solution appeared as possible these clusters were named the same way as done by [3] in similar type of study. Thus cluster 1 was named "all important". Similarly cluster 2 was named "middle of the road" and cluster 3 named as "traditionalists". Cluster 4 was named "price conscious". Finally the lowest response of cluster 5 was named "minimalists". More details of the analyses are provided in Table I.

TABLE I: THE MEAN VALUES OF THE CLUSTER SOLUTION

\begin{tabular}{|c|c|c|c|c|c|c|}
\hline Cluster name & $\begin{array}{l}\text { Middle of the } \\
\text { road }(38.6 \%)\end{array}$ & $\begin{array}{l}\text { All Important } \\
(23.55)\end{array}$ & $\begin{array}{l}\text { Trad'lists } \\
(20.8 \%)\end{array}$ & $\begin{array}{l}\text { Price Conscious } \\
(9.0 \%)\end{array}$ & Minimalists (8.1) & Mean \\
\hline Price & 5.03 & 3.35 & 5.64 & 5.93 & 3.33 & 4.66 \\
\hline Parts & 4.92 & 3.5 & 5.62 & 6.33 & 4.11 & 4.90 \\
\hline Processes & 5.17 & 3.83 & 5.93 & 5.93 & 4.22 & 5.02 \\
\hline Aesthetics & 5.16 & 3.86 & 5.81 & 5.87 & 4.3 & 5.00 \\
\hline Water & 4.84 & 3.85 & 5.84 & 6.1 & 4.63 & 5.05 \\
\hline Impact & 5.05 & 3.88 & 5.93 & 6.33 & 4.85 & 5.21 \\
\hline Design & 5.27 & 3.97 & 6.03 & 6.17 & 4.96 & 5.28 \\
\hline Quality & 5.24 & 3.85 & 5.9 & 5.7 & 5 & 5.14 \\
\hline Display & 5.27 & 3.91 & 5.88 & 6.23 & 5 & 5.26 \\
\hline Memory & 5.23 & 3.96 & 5.96 & 6.23 & 4.7 & 5.22 \\
\hline Battery & 5.5 & 3.9 & 6.06 & 6.33 & 5.3 & 5.42 \\
\hline Roaming & 4.98 & 3.82 & 5.93 & 6.1 & 5.15 & 5.20 \\
\hline Safety & 5.36 & 4.08 & 6.03 & 5.87 & 5.33 & 5.33 \\
\hline Ease & 4.81 & 3.5 & 5.59 & 6.07 & 3.52 & 4.70 \\
\hline Brand & 5.01 & 3.67 & 5.71 & 6.2 & 4 & 4.92 \\
\hline Support & 5.24 & 3.94 & 6.07 & 6.2 & 4.59 & 5.21 \\
\hline Games & 4.67 & 3.76 & 5.52 & 5.7 & 4.48 & 4.83 \\
\hline Tones & 4.77 & 3.73 & 5.75 & 5.57 & 4.48 & 4.86 \\
\hline Language & 5.19 & 4.04 & 6.04 & 6.17 & 4.74 & 5.24 \\
\hline Business services & 5.12 & 3.86 & 5.93 & 6.2 & 4.15 & 5.05 \\
\hline Mean & 5.09 & 3.81 & 5.86 & 6.06 & 4.54 & \\
\hline
\end{tabular}




\section{Interpretation}

Both the Korean and Chinese respondents' male youngsters show technical support and games to be all important in comparison to their female counterparts. Language features and product characteristics were important among all respondents. However, female respondents could be segmented for price conscious cluster or segment. Cell phone functions no value (highest usage). The frequency of usage of the various cell phone functions as assets with the scale (frequently during the day $=1$, daily $=2$, $2-3$ times per week $=3$, weekly $=4$, not used at all $=5$ ) as shown in appendix 1 . The phone and SMS features are used on a daily basis and all the other features on a $1-3$ times per week basis. Summary of clusters is provided in Table I.

\section{DISCUSSION AND FUTURE RESEARCH RECOMMENDATIONS}

The purpose of the study investigates whether intersegments segments exists in the multi-country setting of South Korean and Chinese young college students. The study shows that 5 inter-market market segments do exist within these two countries. The interpretation of the clusters was done with country of residence, gender and the usage of cell phone functions (appendix). The first implication of this research is that 5 inter-market market segments do exist among the college students from China and South Korea. These findings do lead to multiple benefits such as cost effiencies resulting from reduced duplication of effort in multiple markets where similar segments exist. This was demonstrated by [25].

A limitation of this study is that since cell phone technology is advancing fast these results may not be valid for long thus study should be replicated to check the longitudinal validity.

\section{REFERENCES}

[1] W. J. Keegan and M. C. Green, Global Marketing, $5^{\text {th }}$ ed. Upper Saddle River, New Jersey: Pearson Education International, 2008, pp. 161-170.

[2] R. Lukose, "Consuming globalization: Youth and gender in Kerala, India," Journal of Social History, vol. 38, no. 4, pp. 915-935, 2005.

[3] M. Haverila, "Market segmentation in the cell phone market among adolescents and young adults," International Journal of Mobile Communications, vol. 9, no. 4, pp. 401-419, 2013.

[4] M. Haverila, "Cell phone feature preferences and gender differences among college students," Asia Pacific Journal of Marketing and Logistics, vol. 25, no. 3, pp. 346-368, 2011.

[5] Y. F. Chen and J. E. Katz, "Extending family to school life: Students' use of the mobile phone," Human-Computer Studies, vol. 67, no. 2, pp. 179-191, 2009.

[6] E. McLeod, "The use (and disuse) of mobile phones by baby boomers," International Journal of Emerging Technologies and Society, vol. 7 , no. 1, pp. 28-38, 2009.

[7] P. J. Auter, "Portable social groups: Willingness to communicate, interpersonal communication gratifications, and cell phone use among young adults," International Journal of Mobile Communications, vol. 5, no. 2, pp. 139-156, 2007.
[8] S. Jha, "Understanding mobile phone usage pattern among College Goers," The ICFAI Journal of Services Marketing, vol. 6, no. 1, pp. 51-61,2008.

[9] E. Sung and R. Mayer, "Students' beliefs about mobile devices vs. desktop computers in South Korea and United States," Computers \& Education, vol. 59, pp. 1328-1338, 2012.

[10] J. E. Katz, M. A. Aakhus, H. D. Kim, and M. Turner, "Cross-cultural comparison of ICTs," in Mediating the Human Body: Technology, Communication, and Fashion, L. Fortunati, J. Katz, and R. Riccini, Eds. Mahwah, NJ: Lawrence Erlbaum, pp. 75-86, 2003.

[11] Korea Internet and Security Agency. (2009). 2009 Survey of the wireless internet usage. [Online]. Available: http://isis.nida.or.kr/eng/board/?pageId=040100\&bbsId=10\&itemId=3 14

[12] I. Im, S. Hong and M. Kang, "An international comparison of technology adoption testing the UTAUT model." Information \& Management, vol. 48, no. 1, pp. 1-8, 2011

[13] Communications Workers of America. (2009). Nationwide study of real-time Internet connection speeds shows U.S. still lags behind other advanced nations, posts small gains last two years. [Online]. Available: http://www.businesswire.com/news/home/20090824006080/en/Natio nwide-Study-Real-Time-Internet-Connection-Speeds-Shows

[14] Nielsen Study. (2011). Mobile youth around the world. [Online]. Available:

http://www.slideshare.net/unbounded/youth-mobile-usage-around-the -world

[15] H. W. Kim, H. C. Chan, and S. Gupta, "Value-based adoption of mobile-internet: An empirical investigation," Decision Support Systems, vol. 43, no. 1, pp. 111-126, 2007.

[16] G. Isıklar and G. Buyuközkan, "Using a multi-criteria decision making approach to evaluate mobile phone alternatives," Computer Standards \& Interfaces, vol. 29, no. 2, pp. 265-274, 2007.

[17] Y. Kamarulzaman, The Adoption of Internet Shopping for Travel Services, Gardiff Business School, Cardiff University, Cardiff, United Kingdom, 2006

[18] J. V. Biljon and P. Kotze, "Modeling the factors that influence mobile phone adoption," in Proc. the 2007 SAICSIA Annual Research, 2007.

[19] G. Islikhar and G. Buyokozkan, "Using a multi-criteria decision making approach to evaluate mobile phone alternatives," Computer Standardization and Interface, vol. 29, no. 2, pp. 265-274, 2007.

[20] V. Oksaman, The Mobile Phone: A Medium in Itself, VTT Technology Research Center of Finland, 2010.

[21] L. Petruzzellis, "Mobile phone choice: Technology versus marketing. The brand effect in the Italian market," European Journal of Marketing, vol. 44, no. 5, pp. 610-634, 2010.

[22] J. W. Totten, T. J. Lipscomb and W. Lesch, "General pattern of cell phone usage among college students: A four-state phone study," Services Marketing Quarterly, vol. 26, no. 3, pp. 13-40, 2005.

[23] S. Dibb and L. Simkin, "Judging the quality of customer segments: Segmentation effectiveness," Journal of Strategic Marketing, vol. 18 no. 2, pp. 113-131, 2010.

[24] P. Hoang, Business and Management, Victoria, Australia: IBID Press 2007.

[25] S. S. Hassan and S. H Craft, "Linking global market segmentation decisions with strategic positioning options," Journal of Consumer Marketing, vol. 22, no. 2, pp. 81-89, 2005.

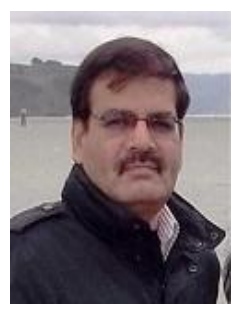

Mahmood A. Awan is an associate professor at SolBridge International School of Business, Daejeon, South Korea. He got his $\mathrm{PhD}$ in Business Administration with specialization in Internet Marketing from Northcentral University in Arizona, USA. He got his undergraduate from McGill University, Montreal and MBA from Alabama A \& M University.

He currently is a chartered marketer (CM) and has over 15 years of Industry experience as well as over 12 years of Academic experience. 